\title{
LOPHOTROCHOZOAN RELATIONSHIPS AND PARASITES. A SNAP-SHOT
}

\author{
BLEIDORN C.*
}

\section{Summary:}

Lophotrochozoa has been consistently recovered in molecular phylogenetic analyses using different markers. Current knowledge of lophotrochozoan relationships is reviewed and the place that parasites occupy in this phylogeny is discussed. Two major taxa are identified within Lophotrochozoa: Platyzoa and Trochozoa. Monophyly of both taxa is still under debate. Relationships within Trochozoa remain largely unclear, however, there is strong evidence that the so called "minor phyla" Sipuncula, Echiura, and Myzostomida are all nested within annelids. Monophyly of the former "Lophophorata" is rejected, and a close relationship between phoronids and brachiopods, as well as between bryozoans and kamptozoans is suggested instead. The movement of the field of systematics into the genomic era will greatly improve our knowledge in the near future.

KEY WORDS : Lophotrochozoa, Myzostomida, parasites, phylogenomic, phylogeny, Platyzoa, Trochozoa.

$\mathrm{P}$ hylogenetics is a fast business in our times. The half-life of large scale phylogenies is sometimes less than the publication speed of many journals. Even though, the aim of this review is to give a picture about what we currently know about lophotrochozoan relationships. Further on, the place that parasites (defined sensu de Meeus \& Renaud, 2002) occupy in this phylogeny is discussed.

The taxon Lophotrochozoa was first introduced in a molecular study of the small ribosomal subunit by Halanych et al. (1995) and later extended by Aguinaldo et al. (1997). In contrast to previous (morphological) studies, their analyses recovered that lophophorates (Brachiopoda, Phoronida, and Bryozoa) are protostomes and closely related to molluscs and annelids (and with flatworms and Rotifera as shown in Aguinaldo et al., 1997).

The taxon Lophotrochozoa was treated sceptically since its description. There is no convincing morphological character uniting all these diverse groups like Annelida, Echiura, Sipuncula, Myzostomida, Mollusca, Nemertea, Kamptozoa, Brachiopoda, Bryozoa, Phoronida, Gna-

* Unit of Evolutionary Biology/Systematic Zoology, Institute of Biochemistry and Biology, University of Potsdam, Karl-LiebknechtStrasse 24-25, Haus 26, D-14476 Potsdam-Golm, Germany.

Tel.: 00493319775604 - Fax: 00493319775070.

E-mail: Bleidorn@uni-potsdam.de thifera, Platyhelminthes, Syndermata, and Cycliophora. However, Lophotrochozoa is consistently recovered in molecular phylogenetic analyses using different markers: combined multigene/EST data (Philippe et al., 2005, Baurain et al., 2007), mitochondrial gene order and sequence data (Helfenbein \& Boore 2004; Larget et al., 2004), ATPase a-subunit (Anderson et al., 2004), hox genes (de Rosa et al., 1999; Passamaneck \& Halanych, 2004), intermediate filament sequence data (Erber et al., 1998), myosin II heavy chain (Ruiz-Trillo et al., 2002), 28 S rRNA (Mallatt \& Winchell, 2002; Passamaneck \& Halanych, 2006), and 18S rRNA (e.g. Halanych et al., 1995).

Whereas the monophyly of Lophotrochozoa seems to be well established (at least in molecular analyses), relationships within this group are only poorly understood. When summarizing lophotrochozoan relationships often a comb-like tree (Fig. 1a) is used for illustration (e.g. in Telford, 2006), indicating that we have not nearly any idea about the relationships. But this

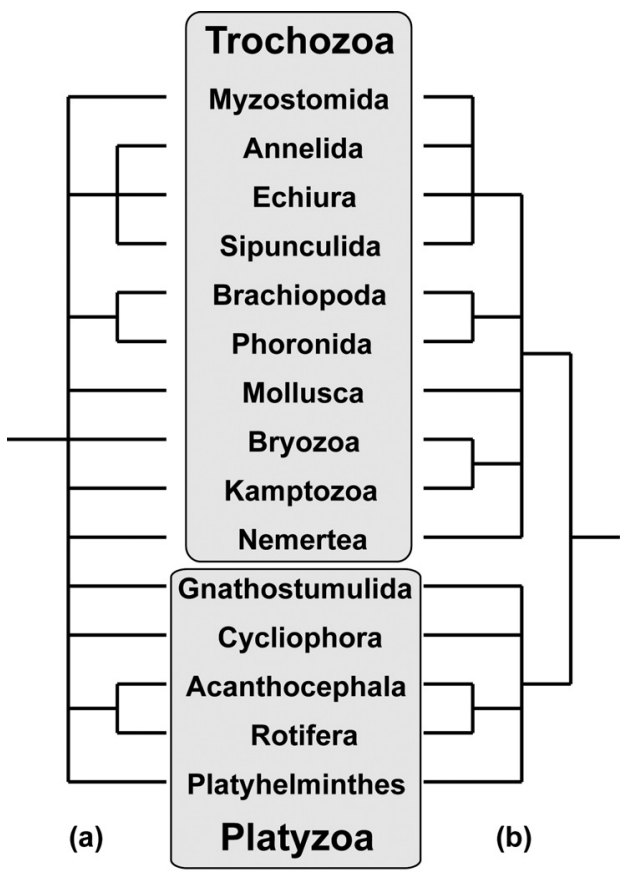

Fig. 1. - Hypotheses of lophotrochozoan relationships: a conservative view (a) and an optimistic view (b). 
is maybe a too pessimistic view. I will try to summarize the current knowledge in the following and a metatree summarising results from different analyses is used for illustration (Fig. 1b).

\section{PLATYZOA}

U sing a combined dataset (morphology + 18S rRNA gene data) Giribet et al. (2000) found Lophotrochozoa to be composed of two sister taxa: Trochozoa and Platyzoa. The Platyzoa comprises flatworms (excluding Acoelomorpha), Gnathostomulida, and the syndermatan taxa, whereas the Trochozoa includes all other Lophotrochozoa. This bipartition can be found also in later analyses (e.g. Philippe et al., 2005; Baurain et al., 2007). Even though, taxon sampling is still scarce for non-flatworm Platyzoa and in some analyses Trochozoa include Platyzoa (e.g. Passamaneck \& Halanych, 2006). Flatworm relationships are discussed in detail in another review paper in this issue.

Besides flatworms, Platyzoa include the syndermatan taxa Rotifera and Acanthocephala. Acantocephalan taxa are endoparasites with a complex life-cycle involving vertebrates as primary hosts; invertebrates (as crustaceans or insects) can serve as intermediate hosts (Westheide \& Rieger, 2007). By contrast, only few parasitic rotiferans are known. Endoparasitic Rotifera belonging to the genera Albertia and Balatro can be found in the guts of earthworms and slugs (May, 1987). Monophyly of Rotifera is still contentious, as bdelloid Rotifera might be sister to Acanthocephala, excluding the monogonont Rotifera (e.g. Garcia-Varela and Nadler, 2006).

\section{TROCHOZOA}

T Trochozoa comprise Mollusca, Annelida, Echiura, Sipuncula, Myzostomida, Brachiopoda, Phoronida, Bryozoa, Kamptozoa, and Nemertea. Name giving is the presence of a ciliated trochophoran type of larvae in these taxa (see Nielsen, 2004, 2005 for review). Relationships of these taxa are still under discussion.

Traditionally, Bryozoa (= Ectoprocta) had been united with Brachiopoda and Phoronida into a taxon Lophophorata (Hyman, 1959), which was assumed to be outside Protostomia. Recent molecular analyses challenged this view (e.g. by Passamaneck \& Halanych (2006) using $18 \mathrm{~S}$ and $28 \mathrm{~S}$ ribosomal gene data). Instead, all these taxa are always recovered within the protostome Lophotrochozoa. A close relationship with Brachiopoda + Phoronida has not been supported in any molecular analyses yet. Instead, resurrecting a hypothesis from Nielsen (2001), Kamptozoa (= Entoprocta) has been recovered as sister taxon of the Bryozoa in a recent phylogenomic analysis relying on ribosomal protein data (Hausdorf et al., 2007). Both taxa contain no parasitic forms.

There is a body of evidence (morphological and molecular) that Phoronida and Brachiopoda are closely related, and phoronids might be even a subtaxon of brachiopods (Cohen, 2000; Cohen \& Weydmann, 2005). No parasitic forms are known for these two taxa.

Still controversially discussed is the phylogenetic position of the unsegmented nemerteans. Whereas Andersson et al. (2004) got support for a sister group relationship to all other lophotrochozoans using data from the ATPase $\alpha$-subunit gene, Passamaneck \& Halanych (2006) recovered them as sister group of the Platyzoa using complete $18 S$ and 28S rRNA gene data. However, recent combined multigene analyses (ribosomal proteins) recovered them as part of the Trochozoa (T. Struck, pers. comm.). Only a few parasitic Nemertea are known. Species of the genus Carcinonemertes are specialized egg predators of decapod crustaceans and most of their life history characteristics are described as parasitic (Roe, 1986). Other nemerteans are known to be parasites of other crustaceans, ascidians, cnidarians and bivalves (Roe, 1988).

The most speciouse taxa within Trochozoa are the Mollusca and Annelida. However the relationships of these two to taxa to other Trochozoa is still unresolved and even monophyly - in both cases strongly supported through morphological characters - has often been not recovered for these taxa (e.g. Bleidorn et al., 2003). Some researchers consider molluscs closely related to annelids (e.g. Nielsen, 2001) - a hypothesis which is congruent with recent phylogenomic analyses (Baurain et al., 2007, Philippe et al., 2005). de Meeus \& Renaud (2002) listed more than 6,000 parasitic taxa for molluscs. For example nearly all members of the gastropod taxon Eulimidae (including more than 800 species) are associated with echinoderms, including ecto- and endoparasitic species (Jangoux, 1987). Triviidae and Lamellariidae (both Gastropoda) comprise many species of obligatory parasites whose life-cycle is closely linked to tunicates. One of the best investigated parasitic molluscs can be found within bivalves. Larvae of freshwater mussels (so called glochidia) are obligate parasites of fish and are usually found encysted on the gills or fins of their hosts (Hastie \& Young, 2001).

Based on embryological data ("molluscan cross") sipunculids are grouped with molluscs by some researchers (Scheltema, 1993). However, molecular phylogenetic studies using mitochondrial genome data (e.g. Bleidorn et al. 2006) and combined 18S, 28S, and elongation factor 1- $\alpha$ data (Struck et al., 2007) clearly supports a nested position within annelids for the sipunculids. Loss of segmentation has to be assumed for sipunculids in this case, and same must be assumed (convergently) for the echiurids, where studies using $18 \mathrm{~S}$ (Bleidorn et al., 2003) as well as the above mentioned 
dataset by Struck et al. (2007) strongly supports a sistergroup relationship to the segmented capitellid polychaetes. Interestingly, Hessling \& Westheide (2002) reported the presence of serially repeated units in the nervous system of echiurids which correspond to typical metameric ganglia of the Annelida.

Heavily disputed is the phylogenetic position of Myzostomida. Myzostomids are usually ectocommensals or parasites of echinoderms and their mosaic like character distribution puzzled researcher since the description of these worms. As annelids, myzostomid possess parapodia-like structures, chitinous chaetae, a ladder-like nervous system, a trochophore-like larva, and serially arranged nephridial organs (Eeckhaut \& Lanterbecq, 2005). However, an annelid affinity has been challenged in recent times by morphological and molecular analyses (Eeckhaut et al., 2000; Zrzavy et al., 2001). These analyses place myzostomids within Platyzoa \& Zrzavy et al. (2001) erected a new taxon called Promastigozoa uniting myzostomids with Syndermata (rotifers and acanthocephalans) - a clade that was mainly supported by spermatozoan ultrastructural characters and $18 \mathrm{~S}$ data. This hypothesis was re-investigated by Bleidorn et al. (2007), who found strong support for an annelid affinity of myzostomids based on mitochondrial sequence data, mitochondrial gene order, and myosin II heavy-chain gene data.

Besides the case of the myzostomids, parasitism evolved many times in annelids. Most prominent are the leeches (Hirudinea) which include many external bloodsucking species. However, parasitic behavior is also known from other clitellates as the naidid Chaetogaster limnaei which is a parasite of mussels of the genus Dreissena (Conn et al., 1996). Parasitic species are also found within polychaetes, as members of the Oenonidae, which live part of there life in the coelom of other annelids (Rouse \& Pleijel, 2001). Other cases of parasitism have been reported from Chrysopetalidae, Nautiliniellidae, Nereididae, and Typhloscolecidae (Martin \& Britaev, 1998; Rouse \& Pleijel, 2001)

\section{CONCLUSIONS}

$\mathrm{L}$ ophotrochozoan relationships are still controversially discussed. We are in a time where phylogenetics is moving into the genomic world. Whereas single gene analyses revolutionized systematics in the mid 90's, today this happens with whole genome data. While writing this review the first three complete genomes of lophotrochozoan organisms have been released (that of the polychaete Capitella sp. 1 (Annelida), the leech Helobdella robusta (Annelida), and the mollusc Lotitia gigantea). More taxa will follow and provide plenty of new data for phylogenetic analyses. Further on, all major lophotrochozoan taxa will be represented by EST-libraries soon (Expressed sequence tags) soon and phylogenomic analyses will (hopefully) give us a clearer picture of the relationships. These new data will show if the current trends and hypotheses reviewed here will be forgotten or written down as text book knowledge.

\section{ACKNOWLEDGEMENTS}

T This study has been supported by the DFG priority program SPP 1174 "Deep Metazoan Phylogeny" (TI 349/4-1 and BL 787/2-1).

\section{REFERENCES}

Aguinaldo A.M., Turbeville J.M., Linford L.S., Rivera M.C., GAREY J.R., RAFF R.A. \& LAKE J.A. Evidence for a clade of nematodes, arthropods and other moulting animals. Nature, 1997, 387, 489-493.

Anderson F.E., Cordoba A.J. \& Thollesson M. Bilaterian phylogeny based on analyses of a region of the Sodium-Potassium ATPase $\alpha$-subunit gene. J. Mol. Evol., 2004, 58, 252268.

Baurain D., Brinkmann H. \& Philippe H. Lack of resolution in the animal phylogeny: closely spaced cladogeneses or undetected systematic errors? Mol. Biol. Evol., 2007, 24, 69.

Bleidorn C., Eeckhaut I., Podsiadlowski L., Schult N., McHugh D., HalanyCh K.M. \& Milinkovitch M.C., Tiedemann, R. Mitochondrial genome and nuclear sequence data support Myzostomida as part of the annelid radiation. Mol. Biol. Evol., 2007, 24, 1690-1701.

Bleidorn C., Podsiadlowski L. \& Bartolomaeus T. The complete mitochondrial genome of the orbiniid polychaete Orbinia latreillii (Annelida, Orbiniidae) - a novel gene order for Annelida and implications for annelid phylogeny. Gene, 2006, 370, 96-103.

Bleidorn C., Vogt L. \& Bartolomaeus T. New insights into polychaete phylogeny (Annelida) inferred by $18 \mathrm{~S}$ rDNA sequences. Mol. Phylogenet. Evol., 2003, 29, 279-288.

COHEN B.L. Monophyly of brachiopods and phoronids: reconciliation of molecular evidence with Linnean classification (the subphylum Phoroniformea nov). Proc. R. Soc. Lond. B, 2000, 267, 225-231.

Cohen B.L. \& Weydmann A. Molecular evidence that phoronids are a subtaxon of brachiopods (Brachiopoda: Phoronata) and that genetic divergence of metazoan phyla began long before the early Cambrian. Org. Div. Evol., $2005,5,253-273$.

Conn D.B., Ricciardi A., Babapulle M.N., Klein K.A. \& Rosen D.A. Chaetogaster limnaei (Annelida: Oligochaeta) as a parasite of the zebra mussel Dreissena polymorpha, and the quagga mussel Dreissena bugensis (Mollusca: Bivalvia). Parasitol. Res., 1996, 82, 1-7.

De Meeus T. \& Renaud F. Parasites within the new phylogeny of eukaryotes. Trends Parasitol., 2002, 18, 247-251. 
de Rosa R., Grenier J.K., Andreeva T., Cook C.E. \& Adoutte A. HOX genes in brachiopods and priapulids and protostome evolution. Nature, 1999, 399, 772-776.

Eeckhaut I. \& LanterbecQ D. Myzostomida: A review of the phylogeny and ultrastructure. Hydrobiologia, 2005, 535/ $536,253-275$.

Eeckhaut I., McHugh D., Mardulyn P., Tiedemann R., MonTeyne D., Jangoux M. \& Milinkovitch M.C. Myzostomida: a link between trochozoans and flatworms? Proc. R. Soc. Lond. B, 2000, 267, 1383-1392.

Erber A., Riemer D., Bovenschulte M. \& Weber K. Molecular phylogeny of metazoan intermediate filament proteins. J. Mol. Evol., 1998, 47, 751-762.

Garcia-VAREla M. \& NADler S.A. Phylogenetic relationships among Syndermata inferred from nuclear and mitochondrial gene sequences. Mol. Phylogenet. Evol., 2006, 40, 6172 .

Giribet H., Distel D.L., Polz M., Sterrer W. \& Wheeler W.C. Triploblastic relationships with emphasis on the acoelomates andthe position of Gnathostumulida, Cycliophora, Plathelminthes, and Chaetognatha: a combined approach of $18 \mathrm{~S}$ rDNA sequences and morphology. Syst. Biol., 2000, 539-562.

Halanych K.M., Bacheller J.D., Aguinaldo A.M.A., Liva S.M., Hillis D.M. \& LAKE J.A. Evidence from $18 S$ ribosomal DNA that the lophophorates are protostome animals. Science, 1995, 267, 1641-43.

Hastie L.C. \& Young M.R. Freshwater pearl mussel (Margaritifera margaritiera) glochidiosis in wild and farmed salmon stocks in Scotland. Hydrobiologia, 2001, 445, 109199.

Hausdorf B., Helmkampf M., Meyer A., Witek A., Herlyn H., Bruchhaus I., Hankeln T., Struck T.H. \& Lieb B. Spiralian phylogenomics supports the resurrection of the Bryozoa comprising Ectoprocta and Entoprocta. Mol. Biol. Evol., 2007, 24, 2723-2729.

Helfenbein K.G. \& Boore J.L. The mitochondrial genome of Phoronis architecta-comparisons demonstrate that phoronids are lophotrochozoan protostomes. Mol. Biol. Evol., 2004, 21, 153-157.

Hessling R. \& Westheide W. Are Echiura derived from a segmented ancestor? Immunohistochemical analysis of the nervous system in developmental stages of Bonellia viridis. J. Morph., 2002, 252, 100-113.

Hyman L.H. The Invertebrates, Vol. 5. McGraw-Hill, New York, 1959.

Jangoux M. Diseases of Echinodermata. II. Agents metazoans (Mesozoa to Bryozoa). Dis. Aquat. Org., 1987, 2, 205-234.

Larget B., Simon D.L., Kadane J.B. \& Sweet D. A Bayesian analysis of Metazoan mitochondrial genome arrangements. Mol. Biol. Evol., 2004, 22, 486-495.

Mallatt J. \& Winchell C.J. Testing the new animal phylogeny: first use of combined large-subunit and small-subunit rRNA gene sequences to classify the protostomes. Mol. Biol. Evol., 2002, 19, 289-301.

Martin D. \& Britayev T.A. Symbiotic polychaetes: Review of known species. Oceanogr. Mar. Biol. Ann. Rev., 1998, 36, $217-340$
MaY L. Epizoic and parasitic rotifers. Hydrobiologia, 1989, 186/187, 59-67.

NiELSEN C. Animal Evolution Interrelationships of the Living Phyla, $2^{\text {nd }}$ edition. Oxford University Press, New York, 2001.

Nielsen C. Trochophora larvae: cell lineages, ciliary bands and body regions. 1. Annelida and Mollusca. J. Exp. Zool. (Mol. Dev. Evol.), 2004, 302B, 35-68.

Nielsen C. Trochophora larvae: cell lineages, ciliary bands and body regions. 2. Other groups and general discussion. J. Exp. Zool. (Mol. Dev. Evol.), 2005, 304B, 401-447.

Passamaneck Y.J. \& Halanych K.M. Evidence from Hox genes that bryozoans are lophotrochozoans. Evol. Dev., 2004, 6, 275-281.

PASSAMANECK Y.J. \& HALANYCH K.M. Lophotrochozoan phylogeny assessed with LSU and SSU data: Evidence of lophophorate polyphyly. Mol. Phylogenet. Evol., 2006, 40, 2028.

Philippe H., Lartillot N. \& Brinkmann H. Multigene analyses of bilaterian animals corroborate the monophyly of Ecdysozoa, Lophotrochozoa, and Protostomia. Mol. Biol. Evol., 2005, 22, 1246-1253.

RoE P. Parthenogenesis in Carcinonemertes spp. (Nemertea: Hoplonemertea). Biol. Bull., 1986, 171, 700-706.

RoE P. Ecological implications of the reproductive biology of symbiotic nemerteans. Hydrobiologia, 1988, 156, 13-22.

Rouse G.W. \& Pleijel F. Polychaetes. University Press, Oxford, 2001.

Ruiz-Trillo I., Paps J., Loukota M., Ribera C., Jondelius U., Baguna J. \& Riutort M. A phylogenetic analysis of myosin heavy chain type II sequences corroborates that Acoela and Nemertodermatida are basal bilaterians. Proc. Nat. Acad. Sci. USA, 1999, 99, 11246-11251.

Scheltema A.H. Aplacophora as progenetic aculiferans and the coelomate origins of mollusks as the sister taxon of Sipuncula. Biol. Bull., 1993, 184, 57-78.

Struck T.H., Schult N., Kusen T., Hickman E., Bleidorn C., McHugh D. \& Halanych K.M. Annelida phylogeny and the origin of Sipuncula and Echiura. BMC Evol. Biol., 2007, 7, 57.

Telford M.J. Animal phylogeny. Curr. Biol., 2006, 16, 981985.

Westheide W. \& Rieger R. Spezielle Zoologie. Teil 1: Einzeller und Wirbellose Tiere. 2. Auflage. Spektrum Akademischer Verlag, München, 2007.

ZRZAVy J., Hypsa V. \& Tietz D. Myzostomida are not annelids: molecular and morphological support for a clade of animals with anterior sperm flagella. Cladistics, 2001, 17, $1-29$. 